\title{
ACCELERATING TOURISM DEVELOPMENT BY COMMUNITY PREPAREDNESS ON DISASTER RISK IN LOMBOK, INDONESIA
}

\author{
Neni WAHYUNINGTYAS \\ Universitas Negeri Malang, Faculty of Social Science, Social Studies \\ Program, Malang, Indonesia, e-mail: neni.wahyuningtyas.fis@um.ac.id

\begin{abstract}
Abdul KODIR
Universitas Negeri Malang, Faculty of Social Science, Department of Sociology, Malang, Indonesia, e-mail: abdul.kodir.fis@um.ac.id
\end{abstract} \\ Idris IDRIS* \\ Universitas Negeri Malang, Faculty of Social Science, Social \\ Studies program, Malang, Indonesia, e-mail: idris.fis@um.ac.id

\section{Naufal ISLAM} \\ Universitas Negeri Malang, Faculty of Social Science, Geography \\ Department, Malang, Indonesia, e-mail: mnaufalislam110999@gmail.com
}

\begin{abstract}
Citation: Wahyuningtyas, N., Tanjung, A., Idris, I. \& Islam, M.N. (2020). ACCELERATING TOURISM DEVELOPMENT BY COMMUNITY PREPAREDNESS ON DISASTER RISK IN LOMBOK, INDONESIA. GeoJournal of Tourism and Geosites, 29(2), 545-553. https://doi.org/10.30892/gtg.29213-488

Abstract: Disaster is a threat to the tourism sector. The losses incurred both material and non-material are one of the tangible forms of interaction between the tourism sector and the disaster phenomenon. This study aims to provide an overview of the preparedness of the community in the area of tourism in responding the phenomenon of disaster and its implications for the tourism sector. This study used a qualitative method with a descriptive approach. The results showed that the community lacked preparedness in facing disasters. Indicators of assessment of preparedness including preparedness for knowledge and attitudes, policies, emergency response plans, disaster warning systems, and resource mobilization. The lack of community preparedness for disaster risk has implications for disaster mitigation management that is not working correctly according to tourism management standards.
\end{abstract}

Key words: community preparedness, disaster risk, tourism development, Lombok

\section{INTRODUCTION}

Disaster is a term that is very familiar to the people of Indonesia. The various impacts caused by disaster activities are not a new reality for Indonesia. Various

\footnotetext{
* Corresponding author
} 
disasters, such as earthquakes, tsunamis, floods, landslides, typhoons, and tornadoes, occur in almost all corners of the country (Hidayati, 2008). It is undeniable that based on a geological review, Indonesia is a region that is in a collision of three large plates such as Eurasia (Europe-Asia) from the North, Indo-Australia from the South, and the Pacific Plate from the East (Puturuhu, 2015; Wahyuningtyas et al., 2019).

This condition not only contributes to abundant natural resources both biological and non-biological but also impacts the magnitude of the potential for disasters in Indonesia. In 2018, there were 2,930 disasters occurring in Indonesia, both geological and hydro-meteorological disasters. These disasters included floods 760 times, landslides 548 times, tidal waves 35 times, waterspouts 997 times, drought 130 times, forest and land fire 374 times, earthquakes 30 times, tsunami twice, earthquake and tsunami two times, and volcanic eruptions 52 times (BNPB, 2017).

Such conditions, both directly and indirectly have an impact on losses experienced in areas that have a vulnerability to disaster activities. Material and nonmaterial impacts are one illustration of how spatial interacts with the phenomenon of disaster. The loss of lives, damage to public facilities, even to the paralysis of several vital sectors, especially in the tourism sector both at the regional and national scale are inevitable. At the same time, the tourism sector has had a massive impact on a country, especially in the region. Also, the role of the tourism sector indirectly provides significant economic opportunities for people's lives (Orhan, 2016).

According to analysis from the World Travel and Tourism Council and the World Bank in 2016, the growth of the Gross Domestic Product (GDP) in the tourism sector is above the industry average. The tourism sector is the 4th rank of national foreign exchange earner, amounting to $9.3 \%$, the highest foreign exchange revenue growth in a country, by $13 \%$, marketing costs $2 \%$ of foreign exchange projections, and contributing 9.8 million jobs, with a percentage reaching $8,4 \%$. It also can create employment by $30 \%$ in 5 years and create the cheapest US \$5,000/job (Suwena \& Widyatmaja, 2017).

If explored more deeply about the potential in such a large tourism sector, it turns out it has a variety of complex problems. Disaster problems in macroeconomic studies have quite crucial impacts on a country (Murray \& Watson, 2019). According to BNPB data, it states that in 2018, Indonesia's tourism sector would receive losses due to natural disasters of Rp. 12.4 trillion, with 4,636 tourists (victims of natural disasters) (BNPB, 2017). Previous research conducted by Artiani (2011) explicitly stated that disasters could disrupt tourism activities in the affected areas, mainly related to disruption of macroeconomic sector indicators such as GDP (Gross Domestic Product), Gross investment, the balance of payments, and public finance.

One example of a disaster affecting activities in the tourism sector is reflected in the conditions of Indonesian tourism in 2018, precisely in Lombok, West Nusa Tenggara. Lombok Island is one of the ten national tourism priority areas developed by the tourism ministry. The earthquake that occurred in 2018 not only brought physical and mental impacts on the victims but also had an impact on the tourism sector. The impact of economic losses due to the earthquake is estimated to potentially lose foreign tourists in one month (6 August - 6 September 2018) around 100,000 tourists with losses reaching USD 100 million, assuming USD 1,000 per visit. Furthermore, spatially, the area affected by the disaster in the tourism sector includes important tourism objects on the island of Lombok consisting of climbing areas of Mount Rinjani, Gili Terawangan, Gili Meno and several other places on the island of Lombok (Adha, 2019).

One of the tourism sectors affected by the 2018 Lombok earthquake is the tourist area of Tangsi Beach (Pink Beach), Sekaroh Village, Jerowaru District, East Lombok Regency. Tangsi Beach Tourism is one of the two leading tourism destinations in East 
Lombok Regency besides Paradise Beach. The Tangsi Beach area is included in eight key destinations on Lombok Island besides Senggigi Beach, Gilli Island, Selong Belanak, Sade Beach, Mount Rinjani, Tanjung Aan, and Pura Meru Temple (Adha, 2019).

Despite having such great potential, the pink beach also faces several problems, including the vulnerability to disaster hazards. One of the threats that affect the existence of the tourism sector in Tangsi Beach is the existence of natural disasters. In general, the threat of disasters such as earthquakes, tsunamis, extreme waves and abrasion, fires, extreme weather, drought, and landslide hazards are serious concerns that need to be addressed primarily in the tourism area (Riyadi, 2016). The role of community preparedness as an actor in dealing with and interacting with disasters needs to be encouraged in order to increase capacity in minimizing the impact of disasters. Losses due to disasters are closely related to the low awareness and preparedness in facing the threat of danger such as the low aspects of preparedness in preparing, preventing, taming, overcoming, and defending themselves from the disasters (Oloruntoba et al., 2018).

Capacity is one element in describing disaster activity that is negatively correlated with vulnerability and danger in the function of disaster risk. Capacity illustrates the ability of an area in dealing with disasters. The role of capacity is enormous in contributing to reducing the risk of disasters. Capacity or resilience is a positive aspect of the existing situation which if mobilized can reduce vulnerability and minimize an area's risk of disaster (Rosyidie, 2004). The capacity for reducing disaster risk has a central role in disaster mitigation activities. This aspect is reflected in the preparedness of the community in the scope of the disaster. Some literature has discussed the community preparedness. Puturuhu (2015) briefly alluded to the importance of community preparedness in responding to disasters, some issues regarding disaster, to its impact which was influenced by the low awareness and community preparedness in responding to disasters. Rosyidie (2004) indicated that the role of capacity which is an essential element of contributing preparedness could minimize the impact of disasters on the tourism sector. Capacity cannot be realized without the aspect of community preparedness in responding to disasters.

The resilience of an area in the tourism sector affects tourist visits. The need for safety for tourists who are at the destination is a top priority in viewing disasters as a factor in the disruption of the development of the tourism sector. The low level of community preparedness for the high vulnerability of Teluk Pelabuhan Ratu as one of the Leading Tourism Areas was also examined by Paramesti (2011). The assessment of the determination of the leading tourism area is based on the location's uniqueness and the high intensity of tourist visits. In addition, the aspect of community preparedness in disaster is the orientation of the development of sustainable tourism.

\section{MATERIALS AND METHODS}

The method used in this study is descriptive qualitative with a case study approach. This approach was chosen based on the location of the study which has the main characteristics related to the topic. Case studies are research on certain cases in more depth by involving the collection of various sources of information (Raco, 2010). The primary data were collected through interviews, observations, documentation, while secondary data were taken from literature studies such as documentation (photos), journals, books, and various other supporting documents.

Leading tourism destinations in East Lombok with inadequate infrastructure development and high vulnerability to disaster risk was the focus of this study and assumed as the appropriate object rather than other places in Lombok. The research was conducted in May to December 2018 and it emphasizes disaster mitigation in the tourism sector, specifically disaster mitigation in Tangsi Beach, Sekaroh Village, Jerowaru 
District, East Lombok, West Nusa Tenggara, Indonesia. The informants consisted of the people of around Tangsi beach, headman and village officials of Sekaroh, coordinator of local community, and the victims of earthquake in 2018.

\section{RESULTS AND DISCUSSIONS \\ Tangsi Beach}

Tangsi Beach or Pink Beach is one of the leading tourist destinations in East Lombok, West Nusa Tenggara, Indonesia. The beauty of nature in the form of exotic pink beaches and historical tourism aspects offered is the main attraction for both local and foreign tourists. The meaning of Tangsi Beach in Indonesia is a barracks or hiding place (Fanny \& Raditya, 2014). The name refers to the history of the arrival of Japanese troops in 1942 who made barracks in the area. The strategic condition of the beach with the shoreline directly facing the sea causes this location to be a strategic military area of Japan in overseeing the Allies. There are many caves and former Japanese military equipment found along the coast and its surroundings.

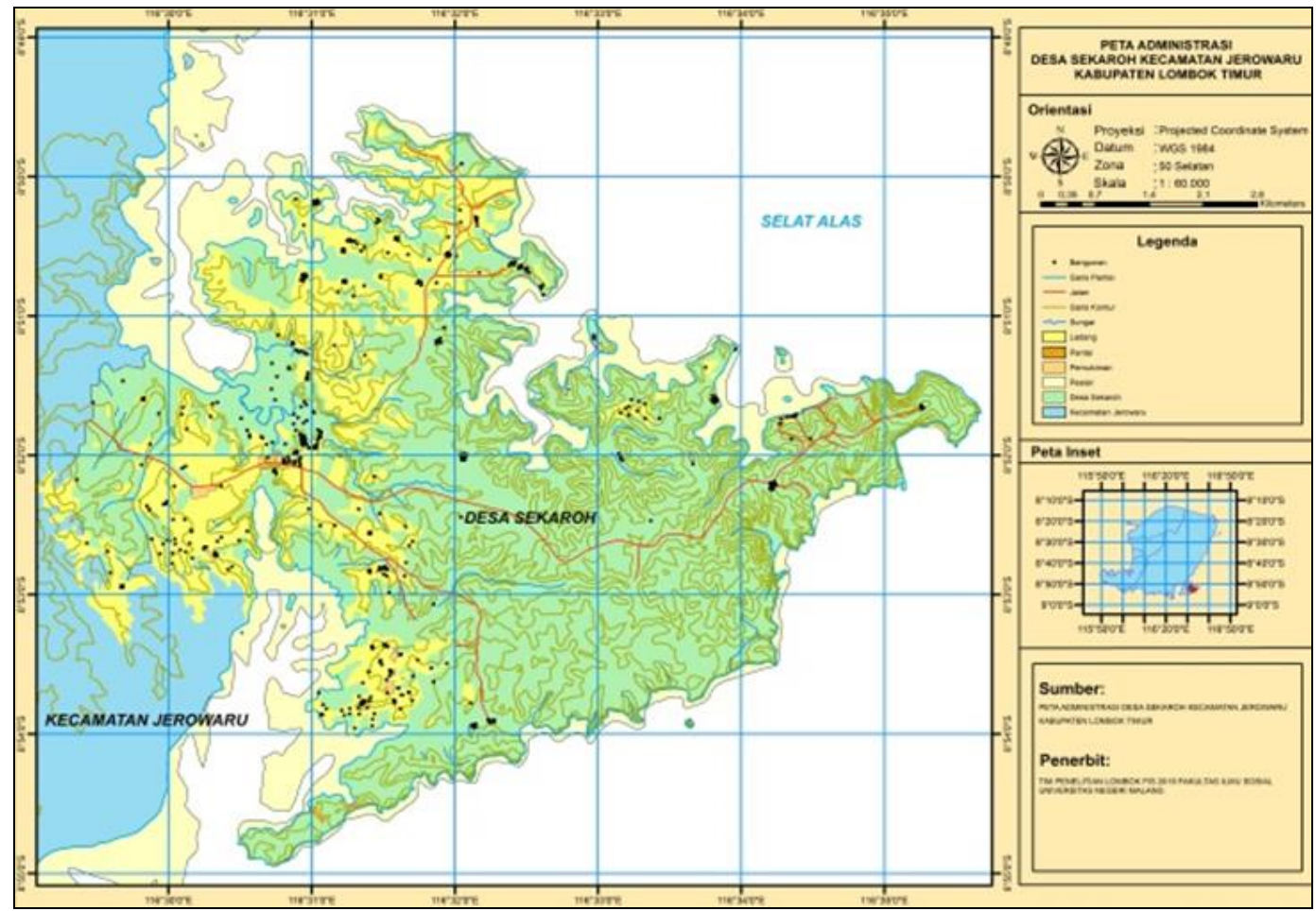

Figure 1. Map of Sekaroh Village, Jerowaru-East Lombok, Indonesia

(Source: BPS East Lombok, 2019)

In terms of accessibility, Tangsi Beach (Pink Beach) is $80 \mathrm{~km}$ from the center of Mataram City with an estimated relative distance of 2.5 hours. The beauty of the pink beach is an asset for the region in particular considering the uniqueness of the pink beach which is one of the seven beaches in the world and one of the two beaches in Indonesia with pink sand (Permadi et al., 2018; Saufi et al., 2019).

Pink Beach is located in Sekaroh Village, which is one of the 15 villages in the Jerowaru District, East Lombok. Administratively, Sekaroh is a village formed by 
Pemongkong Village in the same sub-district. The village consists of seven hamlets including Pengoros, Aro Inak, Ujung Gol, Ujung Ketangga, Telone, Sunut, and Transmigration. Geographically, Sekaroh is a coastal area with elevations ranging from o - 12 meters above sea level, has an annual rainfall of $600 \mathrm{~mm} / \mathrm{year}$ and average temperature ranges from $30-40{ }^{\circ} \mathrm{C}$. Demographic conditions range from 4821 inhabitants spread across seven hamlets. The total number of family heads who live in Sekaroh reaches 1863 families. In terms of livelihoods, in general, there are two leading potential economic sectors of society such as agriculture and tourism. Agriculture includes both land agriculture (rice fields and fields) and marine farming (ponds).

Leading potential tourism associated with the tourism sector both natural and artificial is the Pink Beach area (Tangsi Beach). The prospect of developing the tourism sector in the Tangsi beach area is very high. Various natural resources and educational tours based on historical tourism are essential aspects that become tourist attractions. According to Fadrika in Rayadi (2016) Tangsi Beach has a regional suitability index of $84.61 \%$. This means that the area has high potential as a tourist attraction.

Furthermore, from the disaster aspect Rayadi (2016) through his research entitled "Potential Study for Ecotourism in Tangsi Beach, East Lombok Regency, West Nusa Tenggara Using Swot Analysis" includes the attribute of disaster as one of the elements of threats in addition to competition with other tourism objects. Thus, it is necessary to study the condition of Tangsi Beach community preparedness in order to accelerate the development of tourism based on disaster mitigation.

\section{Community Preparedness}

Preparedness is a crucial element in disaster. This element becomes an important parameter for assessing how much the community in the affected area reduces disaster risk. Various efforts both in the implementation of the concept of mitigation structurally and non-structurally became the main priority in community preparedness in the interaction with disaster. The emphasis on community preparedness is rooted in the people who experience and are affected exclusively about disasters.

Thus, it is necessary to develop a disaster mitigation framework concerning community-based disaster risk reduction. The community preparedness framework is needed as a standard to find out what needs to be prepared before, a moment, and immediately after a disaster occurs (Hidayati, 2008). This framework is used as a tool to assess the extent of community preparedness in an area (Houston et al., 2019). This framework has been based on the LIPI-UNESCO / ISDR standard in 2006, which includes knowledge and attitudes, policies, emergency response plans, disaster warning systems, and resource mobilization (Paramesti, 2011).

\section{Knowledge and Attitude}

Knowledge is a series of processes in humans by utilizing all the sensing components in interpreting certain phenomena. In general, knowledge gives a picture to humans about a past phenomenon to be used as a lesson in the future. Disaster knowledge is the ability to remember events or series of events that threaten and disrupt people's lives and livelihoods caused by both natural and non-natural factors as well as human factors that can cause human casualties, environmental damage, property losses, and psychological impacts (Adiwijaya, 2017).

In the aspect of knowledge about disasters, people around Tangsi Beach are only able to explain the definition of disaster and the types of general natural conditions that cause disasters. Communities around Tangsi Beach, on the aspect of knowledge about disasters, are only able to explain the definition of disaster and the types of general natural conditions that cause disasters. Respondents explained that the area was only affected by several disasters in the low category. Whereas, according to the BNPB (2017) 
disaster risk index in Sekaroh, in general, and Tangsi Beach tourism area, in particular, were categorized as moderate to high with types of disasters including drought, forest fires, earthquakes, and tsunamis. All types of disasters have the potential risk of impacting people's lives (Nolet, 2016; Rindrasih et al., 2018; Van Manen et al., 2015).

In general, respondents explained about the disasters around Tangsi Beach that community knowledge was the result of the reconstruction of life experiences. The lack of experience of disasters in people's lives makes the community seem to rule out the risk of disasters that can occur at any time. This is theoretically confirmed that the absence of one's experience, psychologically, will tend to be harmful towards the object and personal attitudes are formed based on the strong impression experienced by a person (Ningtyas, 2015). Experience gives a significant influence on community preparedness. The lack of experience has an impact on the low level of community response to the phenomenon of disaster. Yulkardi et al. (2012) found that there was a close relationship between experience and community attitudes that were manifested in community action systems in disaster-prone areas.

The description of receiving information about disaster content is also obtained only limited to the type of emergency response information from the relevant agencies or institutions, only information on the current condition of disaster phenomena in some spatial regions. Efforts to deepen the types of disasters that affect Tangsi Beach tourism area in terms of vulnerability, risk, and history of disasters, have not been undertaken by tourism managers and the community. Thus, the position of information literacy regarding disaster is needed especially for the preparedness of the community in disaster-prone areas. This is relevant to the findings of Marlyono et al. (2017) that information literacy has an impact on community preparedness of 46 percent. This means that the position of information literacy related to disaster holds almost 50 percent in the aspect of community preparedness in responding to disasters.

\section{Policy Making}

Regarding the policy parameters in community preparedness in responding to disasters, the form of the policy is a collective agreement. The geographical condition of Tangsi Beach, which is faced with hills in the coastal area is an alternative gathering point during the evacuation process. Community initiatives in the evacuation proces $\mathrm{S}$ are a form of community response in the spatial. In summary, these conditions can be explained by the behavior-environment interaction model in which the response to the environment is a form of mutual influence between moderator variables (social and individuals) as intermediaries and variable mediators (internal processes) as recipients (Veitch \& Arkkelin, 1995). The results of these interactions are manifested in the results of evaluations or evaluations of mediator variables, whether the environment is rated as pleasant or unpleasant. In this context, the response of the community around the Tangsi beach to their environment illustrated the environmental conditions which were seen as pleasing (comfort and safety) in responding to disaster risks.

\section{Emergency Response Plan}

The community divided the emergency response plan into several indicators, including plans to respond to emergencies, evacuation plans, first aid, meeting basic needs, equipment and supplies, essential facilities, and preparedness training. For plans to respond to emergencies, the people of the Tangsi beach area, in general, are not optimally implemented. This is indicated by the absence of division of tasks and roles in emergencies. Distribution of its primary role in emergency response situations is needed to reduce the impact of disasters (Burger et al., 2019). The survey results on disasters that occurred in Japan (the Hansin-Awaji 1995 earthquake) showed the importance of the division of roles in disasters. The percentage of survivors $34.9 \%$ was obtained from saving 
themselves, $31.9 \%$ were helped by family members, $29.1 \%$ were helped by friends or neighbors, $2.60 \%$ were helped by passers-by, and $1.70 \%$ were helped by rescue teams.

The evacuation process is simple, only away from the coastal location at high tide. Regarding the evacuation plan, there are no maps, evacuation routes, even no unique places for evacuation during disasters around the beach. While relating to aspects of first aid based on observations is also not yet available. Furthermore, meeting basic needs was found to be very low. This is based on the low accessibility which is one of the obstacles for the Tangsi beach community. Connectivity with several vital facilities such as hospitals, fire stations, police stations, drinking water companies, electricity, and telecommunications makes the community have low preparedness. Related to simulation activities, informants stated that during their lives in the area the disaster simulation activity was never held. The unavailability of access to material and disaster preparedness education and the low frequency of training is closely related to accessibility (Kachali et al., 2018).

\section{Disaster Warning System}

Indicators of community preparedness in responding to disasters consist of traditional, technology, dissemination of warnings and mechanisms, as well as exercises and simulations. Traditionally people know various characteristics of disasters based on spatial conditions such as tides seen from the full moon and the rotation and revolution of the earth towards other celestial objects. Technologically, they use digital literacy related to high disaster information. The use of various disaster-related applications as well as an understanding of the messages conveyed about disaster is also implemented by the community. This is relevant to the findings of Asteria (2016) that in brief the role of information in the aspect of disaster has a function as socialization and education to shape community preparedness for disasters. The obstacle in the disaster warning system lied in the dissemination of warnings, mechanisms, and simulations.

Geographical conditions that are not supported with relatively difficult outreach become their obstacles in community preparedness. Geographical conditions that tend to isolate people from the outside world are both obstacles and challenges. This is consistent with the findings of Sudibyakto (2018) that one of the characteristics of a disaster location is always associated with difficult accessibility. This situation has an impact on the socialization process which is only limited to obtaining information digitally, and usually the frequency of access to obtain disaster warning information is shallow. In addition, another finding is that evacuation route maps, disaster risk maps, installation and EWS (Early Warning System) applications based on field observations were not found. The implementation of various media in the warning system is also essential in the aspect of disaster. In the Tangsi coast area, it was found that the use of various media warning systems was very minimal. The lack of a warning system in disaster-prone areas will have a significant impact on community preparedness. There is a positive relationship between the existence of an early warning system on community preparedness for disasters (Anwar, 2012; Oloruntoba et al., 2018; Rindrasih et al., 2018). In this case, the position of the warning system plays a vital role in community preparedness.

\section{Mobilization of Resources}

Resource Mobilization, in general, is related to human resource management in disaster reviews. The purpose of the procurement of human resource management is to increase the resilience of the disaster area community. The role of socialization and education both from the community and related institutions is needed. In this context, it has not yet emerged in the Tangsi Beach tourist area either in terms of human resources or funding. The community only relied on the existence of a tourism awareness group (POKDARWIS), which incidentally was limited to the tourism sector rather than disaster. The purpose of Pokdarwis is as a government partner in increasing public awareness in 
the field of tourism, increasing human resources, encouraging the realization of "Sapta Pesona" (security, order, beauty, coolness, cleanliness, hospitality, and memories), improving the quality of tourism products in order to improve competitiveness of tourism business (Nurmayasari, 2017). The effectiveness of socialization from government institutions has not been maximal yet. The socialization and education process did not reach the Tangsi Coast community. This condition gives rise to negative perceptions of related institutions such as low public trust in government institutions. Sociologically, the situation experienced by people in the Tangsi Coast region is closely related to social functioning. Social functioning will develop if individuals are satisfied with roles in their lives, and are satisfied with relationships with others. In this case, the government has not yet played its role optimally, and this has an impact on community preparedness especially concerning information disclosure (Appleby-Arnold et al., 2018; Houston et al., 2019; Raharjo, 2013). Acceptance of public outreach and education from the government is one obstacle besides the accessibility factor in preparedness.

The management of the tourism area is legally managed by the Forestry Service considering that geographically the Tangsi Coast area is surrounded by protected forest based on Minister of Forestry Decree No. 8214/kpts-II/2002. The historical point of view of the Sekaroh community, which has a long-standing conflict over land rights has also become a mindset that is embedded in people's lives. The problem of uneven development until the impact of the 2018 earthquake in Lombok also became another cause of the low public trust in the government. People who are affected by disasters often reject efforts to control or order them (Pramono, 2016; Sutton \& Tierney, 2006).

\section{CONCLUSION}

Tourism Development needs to pay attention to community preparedness in responding to disasters. Meeting the basic needs of the community contributes more to the responsiveness of the community in preparing for disasters. Equitable development is a critical factor in community preparedness and regional resilience both physically and economically. The linkage between disaster and tourism positively provides its primary influence concerning tourist visits which impacts on declining regional income, primary revenue in the tourism sector. Integration between stakeholders plays an essential role in the creation of community preparedness in the scope of disaster including tourism.

\section{Aknowlegments}

Special thanks to Universitas Negeri Malang for financial support on this research.

\section{REFERENCES}

Adha, R. (2019). Tourism Promotion Strategy in the West Nusa Tenggara Province Tourism Office (Case Study of PostEarthquake Tourism Promotion on Lombok Island in 2018). Jurnal Ilmu Administrasi Publik, 7(1), 25 -33.

Adiwijaya, C. (2017). The effect of disaster knowledge and community attitudes towards disaster preparedness against landslides (Study in Lawanggintung Village, South Bogor District, Bogor City). Jurnal Prodi Manajemen Bencana, 3(2), 81-101.

Anwar, H. Z. (2012). The vulnerability and response capacity of the people of Padang City to the tsunami hazard. Jurnal RISET Geologi dan Pertambangan, 22(1), 45. https://doi.org/10.14203/risetgeotam2012.v22.57

Appleby-Arnold, S., Brockdorff, N., Jakovljev, I., \& Zdravković, S. (2018). Applying cultural values to encourage disaster preparedness: Lessons from a low-hazard country. International Journal of Disaster Risk Reduction, 31, 37-44. https://doi.org/10.1016/j.ijdrr.2018.04.015

Artiani, L. E. (2011). Macroeconomic impacts of disasters: Interaction of disasters and national economic development. Prosiding Seminar Nasional Informatika, 67-74.

Asteria, D. (2016). Optimizing disaster communication in the mass media as a supporter of disaster management. Jurnal Komunikasi Ikatan Sarjana Komunikasi Indonesia, 1(1), 1. https://doi.org/ 10.25008/jkiski.vii1.30.

$\mathrm{BNPB}, \mathrm{T}$. (2017). Building awareness, alertness, and preparedness in dealing with disasters (II). BNPB. 
BPS East Lombok. (2019). Lombok Timur Regency in Figures 2019. BPS Lombok Timur.

Burger, J., Gochfeld, M., \& Lacy, C. (2019). Concerns and future preparedness plans of a vulnerable population in New Jersey following Hurricane Sandy. Disasters. https://doi.org/10.1111/disa.12350

Fanny, F., \& Raditya, A. (2014). Designing Branding for Pink Beach destinations in East Lombok Regency. Jurnal DKV Adiwarna, 1(4), 12.

Hidayati, D. (2008). Community preparedness: A new paradigm for natural disaster management in Indonesia. Jurnal Kependudukan Indonesia, 3(1), 69-84.

Houston, J. B., Schraedley, M. K., Worley, M. E., Reed, K., \& Saidi, J. (2019). Disaster journalism: Fostering citizen and community disaster mitigation, preparedness, response, recovery, and resilience across the disaster cycle. Disasters. https://doi.org/10.1111/disa.12352.

Kachali, H., Storsjö, I., Haavisto, I., \& Kovács, G. (2018). Inter-sectoral preparedness and mitigation for networked risks and cascading effects. International Journal of Disaster Risk Reduction, 30, 281-291. https://doi.org/10.1016/j.ijdrr.2018.01.029.

Marlyono, S. G., Pasya, G. K., \& Nandi, N. (2017). The Effect of Disaster Information Literacy on Community Preparedness to Disaster in West Java Province. GEA: Jurnal Pendidikan Geografi, 16(2), 116-123. https://doi.org/10.17509/gea.v16i2.4491.

Murray, M., \& Watson, P. K. (2019). Adoption of natural disaster preparedness and risk reduction measures by business organisations in Small Island Developing States-A Caribbean case study. International Journal of Disaster Risk Reduction, 101115. https://doi.org/10.1016/j.ijdrr.2019.101115.

Ningtyas, B. A. (2015). The effect of disaster knowledge on the preparedness attitude of citizens to deal with landslides in Sridadi Village, Sirampog District, Brebes Regency in 2014 [Thesis]. Universitas Negeri Semarang.

Nolet, E. (2016). ‘Are you prepared?’ Representations and management of floods in Lomanikoro, Rewa (Fiji). Disasters, 4O(4), 720-739. https://doi.org/10.1111/disa.12175.

Nurmayasari, D. (2017). Tourism Awareness Group Strategy (Pokdarwis) in Tourism Development in Canggu Village, Badas District, Kediri Regency. Publika, 5(1), 1-14.

Oloruntoba, R., Sridharan, R., \& Davison, G. (2018). A proposed framework of key activities and processes in the preparedness and recovery phases of disaster management. Disasters, 42(3), 541-570. https://doi.org/10.1111/disa.12268.

Orhan, E. (2016). Building community resilience: Business preparedness lessons in the case of Adapazarı, Turkey. Disasters, 4O(1), 45-64. https://doi.org/10.1111/disa.12132.

Paramesti, C. A. (2011). Community Preparedness at Pelabuhan Ratu Bay for Earthquake and Tsunami Disasters. Jurnal Perencanaan Wilayah Dan Kota, 22(2), 113-128.

Permadi, L. A., Asmony, T., Widiana, H., \& Hilmiati, H. (2018). Identification of potential tourism villages in Jerowaru District, East Lombok Regency. Jurnal Pariwisata Terapan, 2(1), 33. https://doi.org/10.22146/jpt.35380.

Pramono, R. (2016). Sociological perspective in disaster management. Jurnal Masyarakat dan Budaya, 18(1), 81-96.

Puturuhu, F. (2015). Disaster Mitigation and Remote Sensing. Graha Ilmu.

Raco, J. R. (2010). Metode penelitian kualitatif: Jenis, karakteristik, dan keunggulannya. Grasindo.

Raharjo, S. T. (2013). Local wisdom, social functioning and disaster management. Share : Social Work Journal, 3(2), 111-125. https://doi.org/10.24198/share.v3i2.10021.

Rayadi, W. (2016). Study of the potential for ecotourism on the Tangsi coast of East Lombok Regency, West Nusa Tenggara using a SWOT analysis. Jurnal Green Growth dan Manajemen Lingkungan, 5(2), $10-17$.

Rindrasih, E., Hartmann, T., Witte, P., Spit, T., \& Zoomers, A. (2018). Travelling without a helmet: Tourists' vulnerabilities and responses to disasters in Indonesia. Disasters, 42(4), $782-803$. https://doi.org/10.1111/disa.12281.

Rosyidie, A. (2004). Disaster aspects of the tourist area. Jurnal Perencanaan Wilayah Dan Kota, 15(2), 48-64.

Saufi, A., Teguh, F., \& Ristanto, H. (2019). The master plan of Lombok island sustainable tourism during $2015-$ 2019. BAPPEDA NTB.

Sudibyakto, H. A. (2018). Quo vadis of Disaster management in Indonesia? Yogyakarta: UGM Press.

Sutton, J., \& Tierney, K. (2006). Disaster preparedness: Concepts, guidance, and research. University of Colorado.

Suwena, I. K., \& Widyatmaja, I. G. N. (2017). Basic Knowledge of Tourism Science. Bali: Udayana.

Van Manen, S., Avard, G., \& Martínez-Cruz, M. (2015). Co-ideation of disaster preparedness strategies through a participatory design approach: Challenges and opportunities experienced at Turrialba volcano, Costa Rica. Design Studies, 4O, 218-245. https://doi.org/10.1016/j.destud.2015.06.002.

Veitch, R., \& Arkkelin, D. (1995). Environmental Psychology: An Interdisciplinary Perspective. Prentice Hall.

Wahyuningtyas, N., Tanjung, A., Idris, I., \& Dewi, K. (2019). Disaster Mitigation on Cultural Tourism in Lombok, Indonesia. GeoJournal of Tourism and Geosites, 27(4), 1227-1235. https://doi.org/10.30892/gtg.27409-428.

Yulkardi, Y., Yunarti, Y., Budiono, A., \& Putro, A. (2012). The experience of natural disasters and community action systems: Perceptions and response patterns. Jurnal Sosiologi Andalas, XII(1), 117-132.

Submitted:

01.02.2020
Revised:

08.04.2020
Accepted and published online 15.04 .2020 